\title{
Policy urgency and development of the highest retail price (HRP) of subsidised fertilizer
}

\author{
Hasim Ashari ${ }^{1, *}$, Imam Mujahidin Fahmid ${ }^{2}$, M. Saleh S. Ali ${ }^{2}$, Daniel Useng ${ }^{3}$, Rangga D. \\ Yofa $^{4}$, Resty Puspa Perdana ${ }^{4}$, Valeriana Darwis ${ }^{4}$, Sudi Mardianto ${ }^{4}$, Sri Hery Susilowati ${ }^{4}$, \\ and Kurnia Suci Indraningsih ${ }^{4}$ \\ ${ }^{1}$ Doctoral Program of Development Studies, Graduate School, Hasanuddin University, Makassar, \\ Indonesia \\ ${ }^{2}$ Professor of Hasanuddin University, Makassar, Indonesia \\ ${ }^{3}$ Doctor of Hasanuddin University, Makassar, Indonesia \\ ${ }^{4}$ Reserchers of Indonesian Center for Agricultural Socio-Economic and Policy Studies Reserchers of \\ Indonesian Center for Agricultural Socio-Economic and Policy Studies, Indonesia
}

\begin{abstract}
Fertilizer price subsidies aim to increase the purchasing power of poor farmers in order to increase their productivity and farm income. This study aims to analyze the urgency of the fertilizer subsidy policy, and the development of the subsidized fertilizer HET ratio and the price of grain at the farmer level. The study was conducted in West Java Province, 2020. The data used include primary data and secondary data. Data analysis was carried out quantitatively and descriptively qualitatively. The results showed that the fertilizer subsidy policy was given to farmers who farmed a maximum of 2 hectares per season. In Indonesia, the total number of households using land with a scale of $<2$ ha reaches $89 \%$, which are small farmers and require input subsidies. Furthermore, the ratio of output prices to urea fertilizer (2012-2021) tends to increase by $0.97 \% / y e a r$. This shows that the development of subsidized fertilizer prices is relatively small compared to the development of government purchasing prices for paddy. Therefore, in order to improve the efficiency of fertilizer use and maintain the volume of subsidized fertilizer in the midst of a limited fertilizer subsidy budget, efforts must be made to be more targeted and efficient.
\end{abstract}

\section{Introduction}

In the agricultural production process there are a number of necessary production factors such as: land, labor, fertilizers, seeds, pesticides and others. Fertilizer is one of the main production factors that are very decisive in increasing the productivity of food crop farming. To increase effectiveness and increase benefits optimally, the main production factors must arrive at farmers with the right six principles, namely: the right amount, the right dose, the right type, the right price, the right quality/quality, and the right time. To

\footnotetext{
"Corresponding author: hasimkementan@gmail.com
} 
ensure the availability and smooth distribution of subsidized fertilizers, the government continues to improve the distribution process to farmers. Therefore, the government seeks in various ways so that fertilizers are available to farmers according to these principles, including through: (1) providing a fertilizer subsidy budget, and (2) distributing subsidized fertilizers through distributors on each line in stages [1].

The fertilizer subsidy policy carried out by the government is seen as being able to ease the burden on farmers. Through the provision of subsidies to fertilizers, it is hoped that the productivity of agricultural products will increase so as to increase production and achieve food self-sufficiency. The government has implemented the fertilizer subsidy policy since the early 1970s. Since then, various policies regarding fertilizer subsidies, both those contained in presidential decrees and ministerial decrees, have been issued. The policy is based on the important position of fertilizer, which is an important input in agricultural production, receiving special attention from the government. Fertilizer subsidies are provided through a fertilizer selling price mechanism, with the aim that the prices circulating in the market do not burden farmers so that they can encourage farmers to increase agricultural production. Subsidized fertilizers are fertilizers that are widely used for the main food crop, namely rice.

The existence of fertilizer inputs for farming is very important. This is as revealed from the results of a study by [2] that the impact of the fertilizer subsidy policy is still being debated until now. On the one hand, the fertilizer subsidy policy is considered to have a positive impact on increasing the productivity of the agricultural sector and farmers' income, especially for food crops. In addition, the results of [3] and [4] which revealed that the support of fertilizer prices through the provision of fertilizer subsidies had an effect on increasing agricultural production, and subsequently increasing farmers' income.

On the other hand, according to the research results of [5] that the fertilizer subsidy policy is still experiencing various problems, especially at the field level, such as: in the planning process for fertilizer needs at the farmer level presented in the Definitive Plan For Group Needs (eDPFGN), the allocation tends to be lower than the proposal, there is a purchase of subsidized fertilizer in the business sector such as large plantations (with a business scale that is far above 2 hectares), there is a moral hazard for business actors (unofficial retailers) who resell subsidized fertilizers at prices above the Highest Retail Price (HRP) due to a fairly large price spread (difference). There is a large difference between the price of subsidized fertilizer and the price of non-subsidized fertilizer that is traded in the market, when formulating the proposal for fertilizer needs not all farmers are well informed, because there are farmers who are not members of farmer groups, so the needs of farmers in this segment are not included in the process. planning for fertilizer needs listed in the subsidized fertilizer eDPFGN, the dynamics of cultivating agricultural land between seasons is due to the existence of land leases and land acquisitions, which generally are not repaired or recorded in each season, and in general the ability of the majority of farmers to buy fertilizer in cash, so they have to pay at harvest at prices above the highest retail price.

Based on the description above, this study aims to analyze the urgency of the fertilizer subsidy policy, the development of the ratio of the highest retail price (HRP) of subsidized fertilizer and the price of grain at the farm level. As well as formulating policy recommendations in increasing the effectiveness of fertilizer subsidies for the agricultural sector. 


\section{Methodology}

\subsection{Theoretical framework}

Based on the theory of demand, it is known that if the price of a used good increases, the use of that good will decrease. According to [6] that the price of a commodity and the quantity demanded are negatively related, with other but equal factors, in other words, the lower the price of a commodity, the greater the quantity demanded, and the higher the price, the lower the price. requested amount. So that the price of goods at the recipient level is cheaper, subsidies can be given.

According to [7], that the type of subsidy based on its form is divided into subsidies in the form of money (cash transfers) and subsidies in the form of goods or in-kind subsidies (in kind subsidies). According to [8] states that subsidies in the form of goods are believed to be more targeted. For subsidies in the form of goods, among others, input subsidies (fertilizer).

Fertilizer subsidies are defined as government budget allocations to cover fertilizer price subsidies, namely the difference between the subsidized price and the non-subsidized price. What is meant by the subsidized price is the highest retail price (HRP), while the nonsubsidized price is the Price of Production Cost (PPC) of fertilizers. According to [9] that fertilizer subsidy is an input subsidy. The formula for the amount of price subsidy per kg of subsidized product can simply be written as follows:

$$
S_{H i}=H_{N S i}-H_{S i}
$$

$\mathrm{SHi}=$ Price subsidy for the ith product per $\mathrm{kg}$

SHi is the price subsidy borne by the government, and HSi is the price paid by the subsidy recipient community. Subsidies on the price of production facilities such as fertilizers have the aim of increasing the purchasing power of poor farmers so that they can buy production facilities in sufficient quantities to increase or maintain their productivity and farm income.

Several studies related to the implementation of fertilizer subsidy policies at the field level show various views on this policy. In general, fertilizer subsidies can increase crop productivity and farm income, especially food crops [10,11, 12, 13].

Furthermore, based on the results of [14], [15] and [16] revealed that the considerable increase in fertilizer prices has prompted some farmers to make adjustments to the use of fertilizers. However, because the increase in fertilizer prices was also followed by an increase in rice prices, the average change in Urea use was relatively constant, the use of SP-36 decreased by 13 percent and the use of $\mathrm{KCl}$ decreased by 24 percent. However, the average rice production still increased by 2 percent. The results of other studies as revealed by [17] that fertilizer is one of the essential inputs in the production process of food crops. Fertilizer can play an optimal role in efforts to increase productivity and production, if there is sufficient water availability and quality seeds are adopted by farmers. The projected need for various types of fertilizers is expected to be met from domestic fertilizer production.

The use of fertilizers with site-specific nutrient considerations can encourage more efficient use of fertilizers. All of this will ultimately help make the use of fertilizers more efficient while protecting the environment and natural resources as a whole. Abroad as in Poland, according to the results of a study by [18] that the aspect of sustainability has been an emerging problem for many years in economics and agriculture. In an effort to create sustainable agriculture has become an important part and become an important policy together. 


\subsection{Data types and data sources}

This research was conducted in Cianjur and Ciamis, West Java, in 2020. The types of data collected in this study include primary and secondary data. Primary data collection was carried out by a survey conducted on 30 respondents of rice farmers. Meanwhile, secondary data was collected from the Directorate of Fertilizers and Pesticides, the Directorate General of Agricultural Infrastructure and Facilities, Jakarta, the Food Crops Agriculture Service and other related institutions such as the official fertilizer kiosk at the research site.

\subsection{Data analysis}

The research data analysis was carried out both quantitatively and qualitatively descriptively. Quantitative analysis is carried out by calculating the development of the highest retail price (2008-2021) of subsidized fertilizer and grain prices as well as the ratio of the price of fertilizer and grain prices. Furthermore, qualitative descriptive analysis is presented with added information from the research location.

\section{Results and discussion}

\subsection{The Urgency of Fertilizer Subsidy Policy}

Although the contribution of fertilizer costs to the cost structure of farming is only $9.43 \%$; $13.44 \%$ and $4.97 \%$ respectively in lowland rice [19], corn and soybean farming, but fertilizer is an important element in efforts to increase food production. Often, the policy and implementation of fertilizer distribution comes to the fore and becomes a hot topic of public debate and is often associated with political issues.

The urgency of the fertilizer subsidy policy based on the important position of fertilizer which is an important input in agricultural production has received special attention from the government. Fertilizer subsidies are provided through a fertilizer selling price mechanism. The aim is that the prices circulating in the market do not burden farmers so that they can encourage farmers to increase agricultural production. With the subsidy policy by the government, it is seen that it can ease the burden on farmers. Through the provision of subsidies to fertilizers, it is hoped that the productivity of agricultural products will increase so as to increase production and achieve food self-sufficiency.

Based on the Ministry of Agriculture Num. 49 of 2020, it is known that the types of subsidized fertilizers are: Urea, SP36, ZA, NPK, Liquid Organic Fertilizer and Organic Fertilizer. The subsidized fertilizers are intended for farmers who: (a) are members of farmer groups; (b) registered in e-DPFGN; (c) show identity; and (d) fill in the form of redemption of subsidized fertilizer. For farmer groups receiving subsidized fertilizers, they consist of: (a) farmers who carry out farming in the food crops, plantation, horticulture, and/or livestock sub-sectors with a maximum area of 2 hectares per season; (b) farmers who carry out farming activities in the expansion of new planting area of food crop subsector, and/or (c) fish cultivators with a maximum cultivation area of 1 hectare per growing season.

Based on Inter-Census Agricultural Survey data [20] that the number of agricultural business households using agricultural land in Indonesia reached 27.22 people. Meanwhile, households that control land with a scale of $<0.5$ ha are around $59 \%$. Furthermore, if we look further, the total land user households with a scale of $<2$ ha, the total reaches $89 \%$. With the dominance of farmers who control land of this scale, and in general the condition 
of their capital capacity is also limited, so that in their farming activities the availability of inputs at subsidized prices will be very helpful. Thus, in general, if there is an increase in the price of inputs, including fertilizers, it will affect the ability of farmers to purchase fertilizer inputs.

The fertilizer subsidy policy can be said to be successful if the community receives benefits from the subsidy to ease the burden of supplying and using fertilizers for their farming activities. Therefore, the implementation is in accordance with the working principle based on the right price, right quantity, right type and right time [21]. Problems that often arise related to the implementation of organic fertilizer distribution are differences in the recapitulation of fertilizer distribution data with the data on the recapitulation of the eDPFGN.

According to the results of [22], the problem of fertilizer subsidies also appears in other Asian countries, namely India. In this country, fertilizer subsidies, including every year the budget used for fertilizer subsidies always increases and is very burdensome for the government. Under these conditions, the cheap price of urea $(\mathrm{N})$ is prone to abuse, both by using excessive and unbalanced doses, as well as by misuse of non-agricultural use and leakage of subsidized fertilizers to neighboring countries. Therefore, it is necessary to think about improving the subsidy scheme, for example through direct cash assistance that is right on target and thinking that the price of domestic fertilizer is determined by the forces of demand and supply.

The results of another study [2], revealed that developing countries tend to maintain fertilizer subsidies so that farmers get cheap fertilizer prices to support increased food production. Based on the simulation results, the policy to increase the Urea and TSP fertilizer subsidies by 15 percent will reduce the Urea and TSP fertilizer prices by 24.54 and 26.70 percent, respectively. This turned out to have a positive impact on increasing rice productivity. The policy of increasing the Urea fertilizer subsidy or TSP then increasing the Urea fertilizer subsidy has a relatively high impact on rice production. In line with the results of the study, where the results of the study of [23], revealed that rice production in Malaysia cannot be sustained without fertilizer subsidies and farmers are not willing to buy their own fertilizers. If the government decides to slowly or drastically remove fertilizer subsidies, it will encourage farmers to buy their own fertilizers to increase their rice production. In such a context, the existence of fertilizer subsidies in Malaysia will increase yields and thereby increase rice production. Elimination of fertilizer subsidies will reduce rice production and consequently reduce the level of rice self-sufficiency.

Some research results such as [24] and [3] suggest that the presence of subsidized fertilizer prices and their balanced use will encourage increased agricultural production and benefit farmers. Further from the results of the study of [25] in Bengkulu Province that rice productivity is largely determined by the use of production factors such as fertilizers, labor, seeds, and pesticides. Increasing the use of Urea and SP-36 fertilizers will still increase the productivity of lowland rice.

\subsection{The development of the highest retail prices for subsidized fertilizers and grain prices}

If we analyze the dynamics of the value of fertilizer subsidies in the last five years (20152020) it can be informed that the value of fertilizer subsidies is almost relatively constant between 2015-2017, ranging from 30.1 trillion to 31.3 trillion in IDR. Furthermore, the value of subsidies tends to decline from 2015 to 2020 . The value of fertilizer subsidies in 2018 decreased to 28.5 trillion in IDR and in 2019 increased again to 29.50 trillion in IDR and in 2020 to 29.70 trillion in IDR With this subsidy value, the volume of subsidized 
fertilizer in 2015 was 7.78 million tons, then starting in 2016 the volume of subsidized fertilizer increased to 9.55 million tons and the volume remained constant until 2018. For the next development, in 2019 and 2020 in line with the subsidy value. When the amount of fertilizer decreases, the volume of subsidized fertilizer also decreases to 8.88 million tons and 8.90 million tons, respectively (Figure 1).

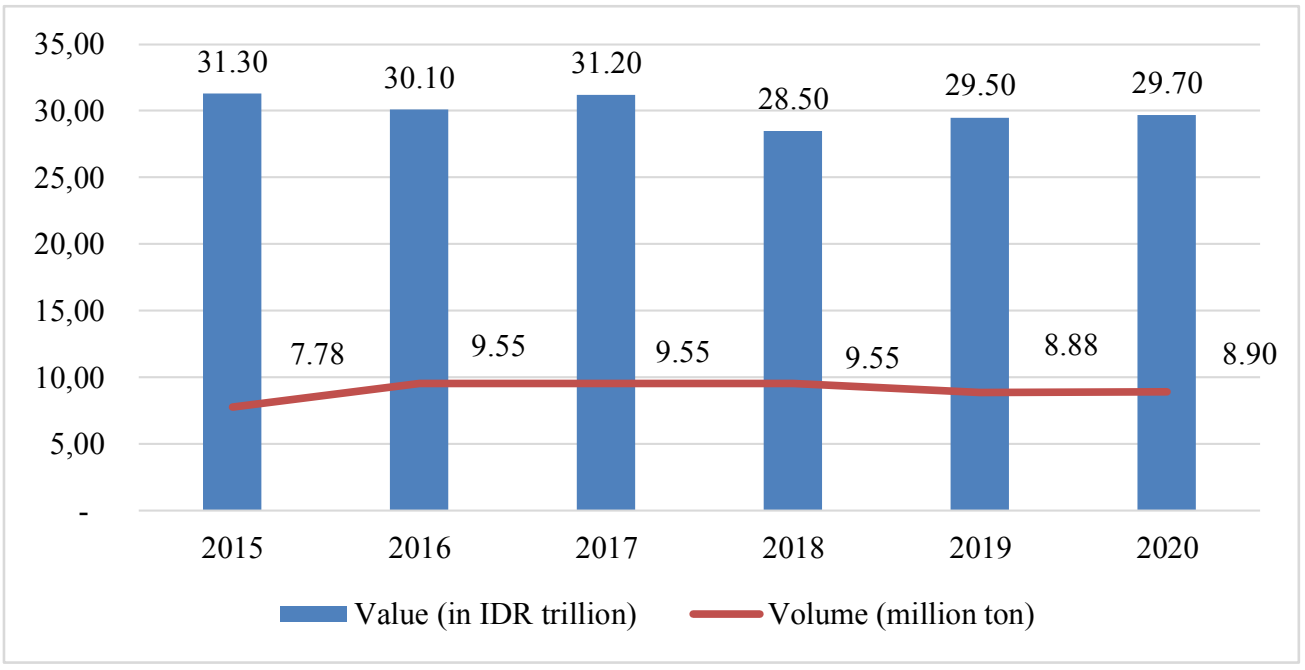

Fig. 1. Fertilizer subsidy development during 2015-2020 [26]

If we look at the development of fertilizer and grain prices, it can be seen that in the period 2008-2021, the price of Urea, ZA, SP-36, NPK fertilizers has increased between $1.79 \%-2.41 \%$ year. Meanwhile, organic fertilizer decreased by $-1.56 \% /$ year. Meanwhile, the price of grain has increased by $4.02 \%$ /year. Furthermore, in the period 2012-2021, it appears that the increase in fertilizer prices ranged from $0.0 \%$ (in NPK fertilizer, which did not increase) to the highest in organic fertilizer at 3.06\%/year and in Urea fertilizer it increased by $1.33 \%$. /year. Meanwhile, the increase in grain prices in this period reached $2.21 \% /$ year. For the government purchase price (GPP) ratio of grain to urea fertilizer, in the 2008-2021 period, it increased by $1.70 \%$ year, and in the 2012-2021 period the increase decreased slightly to $0.975 /$ year. The decrease in this ratio is because the urea HRP as of January 1, 2021 has increased.

In the 2012-2021 period, the HRP for Subsidized Fertilizers for the Agricultural Sector (published annually) did not change, while the GPP for grain had been adjusted several times (Table 1). With these developments, the ratio of the price of fertilizer to the price of grain is getting smaller or in other words the real price of fertilizer is getting cheaper. During the introduction of the Bimas/Inmas program, the term "farmers formula" was known as one of the guidelines for the efficient use of production facilities, including fertilizers, namely the value of one $\mathrm{kg}$ of urea fertilizer used is equivalent to one $\mathrm{kg}$ of grain. With the ratio of the price of fertilizer to the price of grain getting smaller, or the real price of fertilizer getting cheaper, it can encourage inefficiency in input use. Therefore, in the future, fertilizer application must pay close attention to soil nutrient status as well. This is also expressed by the results of research by [27] and [28]. 
Table 1. Development of Subsidized Fertilizer HRP and Paddy GPP in Indonesia 20082021.

\begin{tabular}{|c|c|c|c|c|c|c|c|}
\hline \multirow{2}{*}{ Year } & \multirow[b]{2}{*}{ Urea } & \multirow[b]{2}{*}{$\mathbf{Z A}$} & \multicolumn{2}{|c|}{$\begin{array}{l}\text { Fertilizer price } \\
\text { (IDR/Kg) }\end{array}$} & \multirow[b]{2}{*}{ Organic } & \multirow{2}{*}{$\begin{array}{c}\text { GPP } \\
\text { Paddy } \\
\text { GKP } \\
\text { (IDR/Kg) }\end{array}$} & \multirow{2}{*}{$\begin{array}{c}\text { Ratio } \\
\text { GPP } \\
\text { Paddy to } \\
\text { HRP } \\
\text { Urea }\end{array}$} \\
\hline & & & SP-36 & NPK & & & \\
\hline 2008 & 1,200 & 1,050 & 1,550 & 1,586 & 700 & 2,240 & 1.87 \\
\hline 2009 & 1,600 & 1,050 & 1,550 & 1,586 & 700 & 2,440 & 1.53 \\
\hline 2010 & 1,600 & 1,400 & 2,000 & 1,586 & 700 & 2,640 & 1.65 \\
\hline 2011 & 1,600 & 1,400 & 2,000 & 2,300 & 700 & 2,640 & 1.65 \\
\hline 2012 & 1,800 & 1,400 & 2,000 & 2,300 & 500 & 3,300 & 1.83 \\
\hline 2013 & 1,800 & 1,400 & 2,000 & 2,300 & 500 & 3,300 & 1.83 \\
\hline 2014 & 1,800 & 1,400 & 2,000 & 2,300 & 500 & 3,300 & 1.83 \\
\hline 2015 & 1,800 & 1,400 & 2,000 & 2,300 & 500 & 3,700 & 2.06 \\
\hline 2016 & 1,800 & 1,400 & 2,000 & 2,300 & 500 & 3,700 & 2.06 \\
\hline 2017 & 1,800 & 1,400 & 2,000 & 2,300 & 500 & 3,700 & 2.06 \\
\hline 2018 & 1,800 & 1,400 & 2,000 & 2,300 & 500 & 3,700 & 2.06 \\
\hline 2019 & 1,800 & 1,400 & 2,000 & 2,300 & 500 & 3,700 & 2.06 \\
\hline 2020 & 1,800 & 1,400 & 2,000 & 2,300 & 500 & 3,750 & 2.08 \\
\hline $2021 *)$ & 2,250 & 1,700 & 2,400 & 2,300 & 800 & 4,200 & 1.87 \\
\hline r (\%/year) & & & & & & & \\
\hline $2008-2021$ & 2.40 & 1.97 & 1.79 & 2.41 & -1.56 & 4.02 & 1.70 \\
\hline $2012-2021$ & 1.33 & 1.14 & 1.07 & 0.00 & 3.09 & 2.21 & 0.97 \\
\hline
\end{tabular}

Source: [31,32]

Description: *) New HRP, per 1 Jan 2021.

In addition, the wide difference between subsidized fertilizer prices and non-subsidized fertilizer prices has led to moral hazard actions by unscrupulous market players in the form of fertilizer smuggling, copying subsidized fertilizers and other fraudulent actions. An alternative policy is to narrow the gap between subsidized fertilizer prices and nonsubsidized prices through an increase in HRP. Furthermore, the increase in the HRP for subsidized fertilizers is starting in 2021, with the issuance of Minister of Agriculture No. 49 of 2020 as of December 30, 2020 concerning the Allocation and HRP of Subsidized Fertilizers for the Agricultural Sector in 2021. In addition, monitoring efforts in the field must also continue to be pursued as well as improvements to the distribution system and distribution of subsidized fertilizers to the farmer level. These efforts have now been carried out by the government, and the trend continues to improve and be effective.

Furthermore, based on the Minister of Agriculture 49 of 2020, Article 12 paragraph (2) states, among other things, that the HRP for subsidized urea fertilizer is in IDR 2.250 per kilogram. The previous price based on MoA 69/2012 was IDR 1,800 per kg. In other words, the HRP for subsidized urea fertilizer increased by IDR 450 per kilograms. Thus the price per bag (fill $50 \mathrm{~kg}$ ) of in IDR 90 thousand to in IDR 112,500 or an increase of in IDR 22,500 per bag. SP-36 fertilizer from in IDR 2,000 to in IDR 2,400 per kg. ZA fertilizer from in IDR 1,400 to in IDR 1,700 per $\mathrm{kg}$. Meanwhile, NPK did not increase, which was still in IDR 2,300 per kg. The Special Formula NPK increased by in IDR 300 per $\mathrm{kg}$, from in IDR 3,000 to in IDR 3,300 per kg. Granular organic fertilizer from in IDR 500 to IDR in IDR per $\mathrm{kg}$.

Meanwhile, the price of output (grain) has increased first, with the issuance of the HPP amount stipulated in the Minister of Trade Regulation Num. 24/2020, namely for harvested dry grain at the farm level of in IDR 4,200/ $\mathrm{kg}$ and at the milling level of in IDR 4,250. $/ \mathrm{kg}$, 
dry milled unhulled rice at the milling level is in IDR 5,250/kg and at Bulog's warehouse is in IDR 5,300/kg, and rice in the Bulog warehouse is in IDR $8,300 / \mathrm{kg}$.

Along with the increase in fertilizer HRP which means there is a decrease in the amount of fertilizer subsidies, it is necessary to have an impact on the performance of food crop production, especially rice. By knowing these conditions, it will be necessary what kind of strategy in anticipating it.

According to the results of research by [29], that from the results of policy simulations if the price of input or HRP (Urea fertilizer, NPK, SP 36) increases simultaneously ceteris paribus, while the cost of production of GKP rice remains constant. it will encourage a decrease in the use of inputs which will ultimately affect rice production. If the input price increases and the GPP GKP price increases simultaneously it will encourage an increase in fertilizer use and if the Urea HRP is increased higher than the increase in the NPK and SP 36 HRP it will still encourage the use of more fertilizer but a reduction in the use of Urea fertilizer, which in turn affects the amount of rice production. Meanwhile, the results of a study by [30] showed that in Nigeria the fertilizer subsidy program had a very small effect on increasing grain prices between planting and harvesting seasons. The results also show that political influence plays an important role in the distribution of subsidized fertilizers.

\subsection{Strategy to Increase the Effectiveness of Subsidy for Fertilizers for the Agricultural Sector}

To improve the effectiveness and accuracy of the fertilizer subsidy policy targets, it is necessary to have a valid data base of recipients of subsidies, so that fertilizer subsidies are right on target. Accurate data is very much needed in planning the need for subsidized fertilizers, as a basis for targeted distribution, and evaluating the effectiveness of subsidies.

Obstacles in realizing accurate data, because the target of fertilizer subsidies is actually land and plants, which are managed by farmers. So that the accuracy of the target indicator is that subsidized fertilizers are used to fertilize crops and land that are included in the subsidy criteria, not stopping at the acceptance of fertilizers by farmers. Several obstacles and challenges in realizing accurate subsidy target data are: (1) The complexity of the socio-economic conditions of rural communities, the variety of farming systems, and various land management institutions in the village make data collection of farmers and preparation of subsidized fertilizer needs difficult; (2) Variations in the types of commodities planted and cropping patterns in a year between farmers are very high, the dynamics of the status of cultivation makes updating data on farmers receiving subsidies to be done regularly. Variations in seasonal commodity crop patterns have the potential to cause inaccuracies in calculating inter-season fertilizer requirements; and (3) The dynamics of the pattern of cultivating land every season (lease rent, profit sharing, pawn) has the potential to cause duplication of land area recording between the owner and the cultivator or between the previous and current cultivators.

Responding to the fertilizer subsidy policy that is spent directly by utilizing the difference in subsidized prices that can ease farmers' spending, it is widely used in countries around the world. In African countries, the fertilizer subsidy policy is a very popular expenditure carried out by the government. Responding to efficiency and problems that often arise at the field level, most user farmers expect the availability of commercial fertilizers in the field, this shows that the ability of farmers to buy fertilizers is without a subsidy policy [33].

The use of fertilizers with site-specific nutrient considerations can encourage more efficient use of fertilizers. All of this will ultimately help make the use of fertilizers more efficient while protecting the environment and natural resources as a whole. Abroad as in 
Poland, according to the results of a study by [18] that the aspect of sustainability has been an emerging problem for many years in economics and agriculture. In an effort to create sustainable agriculture has become an important part and become an important policy together. However, in the end, producers/farmers are still the ones who decide for themselves which agricultural practices they apply. Producers' views on the benefits derived from sustainable agriculture vary. However, the two most significant advantages were concluded, namely the protection of water from pollution and the reduction of greenhouse gas emissions.

The direction of government policy in subsidy management is that the subsidy policy is more targeted and efficient. Therefore, recipients of subsidies must be properly recorded and a verification process is carried out in their distribution. Starting in 2019, the proposed eDPFGN for all provinces will continue to increase the use of the eDPFGN system. The use of the Farmer's Card and the eDPFGN system in all provinces needs to be massively encouraged in order to increase efficiency and optimize the use of fertilizers according to the correct 6 principles (amount, dose, type, price, quality/quality and time). Improvements in the preparation of the eDPFGN for subsidized fertilizers and the provision of subsidized fertilizers in accordance with the needs that are compiled based on the DPFGN are one of the main keys in eliminating the problem of scarcity of subsidized fertilizers that has always occurred.

In order to increase the efficiency of fertilizer distribution using the farmer's card, it is necessary to pay attention to several things, especially related to: (a) uniformity of infrastructure and IT systems built by banks, (b) readiness of appointed distributors and kiosks, (c) adequate support of human resources, (d) ) supervision of the application of fertilizer subsidies and (e) supporting infrastructure. At the field level, the implementation of the farmer card is still being improved because it is still facing several technical problems, including those related to the internet network, readiness of EDC operators, and data collection of farmers and other technical problems. These problems need to be addressed immediately for the successful implementation of the farmer card and eDPFGN.

\section{Conclusions and recommendations}

The urgency of the fertilizer subsidy policy is based on the important position of fertilizer which is an important input in agricultural production. The aim is that the prices circulating in the market do not burden farmers so that they can encourage farmers to increase agricultural production. Through the provision of subsidies to fertilizers, it is hoped that the productivity of agricultural products will increase so as to increase production and achieve food self-sufficiency. With a fairly dominant number of small farmers and in general the condition of their capital capacity is also weak, the availability of inputs at subsidized prices will be very helpful.

The fertilizer subsidy policy is given to farmers who cultivate a maximum of 2 hectares per season. In Indonesia, the total number of households using land with a scale of $<2$ ha reaches $89 \%$, which are small farmers and require input subsidies. Furthermore, the ratio of output prices to urea fertilizer (2012-2021) tends to increase by $0.97 \% / y e a r$. This shows that the development of subsidized fertilizer prices is relatively small compared to the development of government purchasing prices for grain. Therefore, in order to increase the efficiency of fertilizer use and maintain the volume of subsidized fertilizer in the midst of a limited budget for fertilizer subsidies, it needs to be handled properly.

Government policies in the management of fertilizer subsidies will be more targeted and efficient, by further improving the data collection and verification process for subsidy 
recipients in their distribution. Improvements in the preparation of the eDPFGN for subsidized fertilizers and the provision of subsidized fertilizers in accordance with the needs that are compiled based on the eDPFGN are one of the main keys in eliminating the problem of scarcity of subsidized fertilizers that has always occurred. The use of the farmer's card and the eDPFGN system in all provinces needs to be massively encouraged in order to increase efficiency and optimize the use of fertilizers according to the right principles (amount, dose, type, price, quality/quality and time). Of course, the readiness of various instruments for the implementation of the farmer's card needs to be well prepared.

\section{References}

1. A. Suryana, A. Agustian, dan R.D. Yofa. Laporan Hasil Penelitian Analisis Kebijakan Pusat Sosial Ekonomi dan Kebijakan Pertanian, Bogor (2015).

2. I. Hermawan, I. J. Ekonomi dan Kebijakan Publik 51 (2014]).

3. A.M. Komareka, S. Drogue, R. Chenoune, J. Hawkins, S. Msangi, H. Belhouchette, G. Flichman. J. Agricultural Systems 154 (2017).

4. V. Theriault, M. Smale. J. Food Policy 102 (2021).

5. B. Prasetyo, P. U. Hadi, N. K. Agustin, C. R. Adawiyah. Laporan Hasil penelitian Pusat Analisis Sosial Ekonomi dan Kebijakan Pertanian Badan Penelitian dan Pengembangan Pertanian Kementerian Pertanian, Bogor (2012).

6. R.G Lipsey. Pengantar Mikroekonomi. 10, 1, Binarupa Aksara. Jakarta (2019).

7. J. Hirshileifer. Teori Harga dan Penerapannya. Erlangga, Jakarta (2012).

8. N.D. Hyman. Public Finance: A Contemporary Application of Theory to Policy. 10, South-Western, Cengage Learning, Nelson Education, Ltd. Canada (2020).

9. R.S. Pindyck, D.L Rubinfeld. Microeconomics Saddle River New Jersey 07458 (2015).

10. World Bank. Fertilizer Subsidies in Indonesia: Policy Note, Indonesia Agriculture Public Expenditure Review, Jakarta (2009]).

11. S.R Singh, D. K Kundu, P.Dey, P. Singh and B.S. Mahapatra. J. Agric. Sci. 1562 (2018).

12. E.T. Jaja and L.I. Barber. J. of Biology, Agriculture and Healthcare, 71 (2017).

13. T. Girma, S. Beyene, B. Biazin. J. of Fertilizers \& Pesticides 8, 3 (2017).

14. T.Tj. Andari. Dampak penghapusan Subsidi Pupuk Terhadap Permintaan Pupuk dan produksi Padi di Jawa Barat, Tesis Pascasarja IPB, Bogor (2001).

15. K.V. Praveen, K.S. Aditya, M.L. Nithyashree, A. Sharma. J. of Crop and Weed Vol.13, 3 (2017).

16. H.M. Khaing, S.S. Mar, H.H. Oo, K. Ngwe. African J. of Agricultural Research. 17, 1 (2021).

17. S. Alimuso, S. Majalah Pangan 19, 1 (2020).

18. M. Gebska, A. Grontkowska, W. Swiderek, B. Golebiewska. Sustainability, 12, 8022 (2020).

19. BPS. Struktur Ongkos Usahatani Padi dan Palawija, BPS, Jakarta (2017).

20. BPS. Survey Pertanian Antar Sensus, Jakarta (2018).

21. S. Marisa. 2011. Analisis Efektivitas Kebijakan Pupuk dan Pengaruhnya terhadap Produksi Padi (Studi Kasus: Kabupaten Bogor), repository .ipb.ac.id. (2011). 
22. G.P.B. Ashok. Rationalising Fertilizer Subsidy in India: Key Issues and Policy Options. Indian Council For Research On International Economic Relations (2015).

23. N.N. Ramli, N. Shamsudin, Z. Mohamed, A. Radam. Int. J. Social. Scienc. Humanit. 2, 3, (2012).

24. R.E. Wako, I.A. Usmane. J. of Food Science and NutritionTherapy (2020).

25. E. Makruf, Y. Oktavia, W. E. Putra. 2012. Makalah Seminar Nasional, BPTP Bengkulu (2012).

26. Kemenkeu. Data APBN: Subsidi Energi dan Non Energi, Kementerian Keuangan (2021).

27. D. Pivoto, P.D. Waquil, E. Talamini, C.P.S. Finocchio, V.F.D. Corted, G.de.V. Mores. J. Information Processing in Agriculture 5 (2018).

28. M. Shinde, K. Ekbote, S. Ghorpade, S. Pawar, S. Mone. 2016. Int. J. comput. sci. inf. technol. res. 7, 2, (2016).

29. R. Nizar, A. Ariyanto. 2016. Pekbis Jurnal 8, 1 (2016).

30. V. Theriault, M. Smale. 2021. J. Food Policy 102 (2021).

31. Kementan. Data Alokasi Pupuk, Kementerian Pertanian, Jakarta (2021).

32. BPS. Data Perkembangan Harga Gabah Bulanan, BPS, Jakarta (2021).

33. H. Takeshima, L. Saweda O. Selected Paper Prepared for Presentation at The Agriculture \& Applied Economics Association's 2013 AAEA\&CAES Joint Annual Meeting, Washington, DC (2013). 